\title{
Lesson Study as a Comprehensive Learning Strategy to Build Students' Character
}

\author{
Sri Mulyani Sabang \\ Universitas Tadulako \\ Palu, Indonesia \\ mulyani_kim@yahoo.com
}

\author{
Suherman \\ Universitas Tadulako \\ Palu, Indonesia
}

\begin{abstract}
The main requirement of independence of a nation is awakening every citizen as a whole, as it is in line with National Education purpose that is building Indonesian people completely. Citizens are completely intelligent human, comprehensive, and competitive, it is necessary for conscious and deliberate effort through formal education. The risk of failure cause of children at school is not only in intelligence but also in the character of students. This research aims to support the revitalization of character education in finding a synergy pattern of cognitive, psychomotor, and attitude. The method used is the identification of the student's character using Lesson Study that focuses on improving the quality of learning and professional development of teachers. Lesson study was carried out in three stages; ie plan, do and see sustainably and collaboratively. The result showed that the nine characters identified in the implementation process of learning the lesson study; namely a religious character, creativity, innovation, activity, discipline, teamwork, hard work, achievement, and responsibility. Initial implementation of learning the ninth character is still low after the study was carried out by applying lesson study, these ninth characters have increased, the student's skills that including observation, communication, measurement, clarification, conclusion, and prediction also have increased. The ninth character and skills of the students have the potential to improve the intelligence of students. These results show that Lesson Study can be used as a comprehensive learning strategy to build the character of students towards the independent nation. Lesson study can improve the quality of national education, and give birth to a generation of people who have competence in terms of cognitive, psychomotor, and attitude be able to answer the challenges of the times is increasingly complex and dynamic.
\end{abstract}

Keywords-lesson study; comprehensive learning; students' character

\section{INTRODUCTION}

Nowadays, the general educational development is still faced with various problems which related to the low quality of education and the low competitiveness of graduates. The problems of education quality do not stand alone but linked in a system of mutual influence such as output, input, and processes.The various policies of government educational processes for teachers such as curriculum improvement. 2017 implementation of the 2013 curriculum entering the 4th year. One focus in the 2013 curriculum implementation is the strengthening of character education in learning. Characterbased learning should be designed in an integrated manner with other learning. Therefore, the competence of teachers in designing learning Teachers is a very central component of the learning process and determine the efforts to improve the quality of education. The teacher contributes a lot to the students' learning independence and learning achievement [1].

Regarding with the paragraph above, we need a coaching strategy for educators (teachers) to become professional teachers. Lesson study is one model that can be used as a strategy to develop teachers' professionalism. Lesson study is a model of professional development for educators through collaborative learning assessment and sustainable based on principles of collegiality and mutual learning to build a learning community [2]. Increasing the character education content into lesson study activities is not adding substance and lesson study materials. The purpose of character education will be achieved by itself because during the process of lesson study in it contains positive activities to bring the habit and will eventually form a positive character. Surely, this is adjusted to the circumstances and conditions of students and the applicable education system.

Teacher professions are closely linked to the political and cultural policies of each country, but they all lead to the development of teacher professionalism in order for all students to learn optimally [3]. A professional teacher is a teacher who is able to provide optimal service to all students who are taught sustainably and continuously.Finally, graduates become independent and have a tough compete globally. At the end, the quality of Indonesian education can be in a group of countries whose quality of education is high as Japan and become an independent nation. The main requirement of independence of a nation is awakening every citizen as a whole, in line with national educational goals stipulated in the Act No. 20/2013 on the National Education System [4] Explicitly, vision of the national education ministry in 2025 said that the Indonesian man who coveted are intelligent human beings, comprehensive, and competitive, which is the direction of education in Indonesia. Learning means changes in personality and is characterized by simultaneous restructuring on aspects of cognitive, emotional, and social dimensions [5, 6]. Therefore, we need a comprehensive learning strategy, the learning process should be more emphasis on the empowerment that equips students with the knowledge, skills, and attitudes as well as to be able to live independently, become independent learners (selfregulated learning).Learning has to be deliberately designed to 
achieve all the planned learning outcomes, particularly the attitude and character. Even a positive attitude and character should be a reference for determining the success of a student. Besides cognitive ability, it also needs the integration of cognitive and positive attitude from the students [7]. The risk of failure cause of children at schools is not only in intelligence but also in the character of students. The character does not come by itself, but shaped and built consciously and deliberately, based on the identity of each other [8]. This research aims to support the revitalization of character education and find a synergy pattern of cognitive, psychomotor, and attitude. Characters do not automatically develop in self-learners. To develop it, it needs to have the presence of social engineering designed and implemented consciously with a clear direction. Lesson study can be used as a strategy through the stages of the plan, do, and see.

\section{METHOD}

This research was carried out in the academic year of 2015/2016 (July 2015-June 2016) in Moutong Parigi regency. The research subject is class XI students of SMAN in Moutong Parigi regency, they were: SMAN 1 Parigi, SMAN Sausu, Tolai SMAN and SMAN Central Parigi.

The method used was the student's character identification using Lesson Study learning design which focuses on improving the quality of learning and professional development of teachers.

\section{A. Stage of Research Implementation}

1. The implementation of lesson study socialization was to the head of Education Board, High School Supervisors, Principals, and Teachers of Mathematics and Natural Sciences (mathematics, physics, chemistry, and biology) of Parigi Moutong district.

2. Identifying academic competence (Mathematics, Physics, Chemistry, and Biology) and character of students (religious, creative, innovative, active, discipline, teamwork, self-reliance, respect for achievement, responsibility).

3. The implementation of Lesson Study that begins the assignment of teacher model. Then, we conducted learning in the following stages:

a. Plan; create a shared learning design that integrates character education.

b. Do; the implementation of learning by teacher models observed by teachers/peers focusing on how students learn.

c. See; reflecting the learning process that has been implemented by the model teacher, then conducted a lesson-based learning redesign for subsequent learning.

4. Quality of student learning outcomes obtained at the end of the odd semester and even semester.5. The quality of students' learning outcomes was obtained at the end of the odd semester and even semester.

\section{B. Technique of Data Collection and Analysis}

1. Identification of academic competence (Mathematics, Physics, Chemistry, and Biology) obtained from secondary data that is student's learning result of semester even the previous academic year (2014/2015) as preliminary data before applied lesson study while skill data and student character are taken by using questionnaire.

2. The quality of student learning outcomes taken at the end of each semester (odd and even) students of class XI in the academic year of 2015/2016 data of learning outcomes was gathered covering domains of cognitive, psychomotor, and attitude. Furthermore, they were described in the narrative.

\section{RESULTS AND DISCUSSION}

\section{A. Before the implementation of lesson study}

This research has succeeded in identifying the cognitive sphere, the sphere of attitude development and the realm of students' science process skills. The results obtained can be seen in Table 1.

TABLE 1. Values of cognitive, psychomotor, and attitudes of the students in class XI academic year of 2014/2015

\begin{tabular}{|l|c|c|c|c|c|c|c|c|c|}
\hline Cognitive & $\mathrm{Ma}$ & $\mathrm{Ph}$ & $\mathrm{Ch}$ & $\mathrm{Bi}$ & & & & & \\
\cline { 2 - 12 } Value & 83 & 77.14 & 79.88 & 84.86 & & & & & \\
\hline $\begin{array}{l}\text { Psychomot } \\
\text { or Value }\end{array}$ & $\mathrm{P}$ & $\mathrm{Q}$ & $\mathrm{R}$ & $\mathrm{S}$ & $\mathrm{T}$ & $\mathrm{U}$ & & & \\
\hline & 29.2 & 21.91 & 50.67 & 4.72 & 18.66 & 34.83 & & & \\
\hline $\begin{array}{l}\text { Attitude } \\
\text { Value }\end{array}$ & $\mathrm{A}$ & $\mathrm{B}$ & $\mathrm{C}$ & $\mathrm{D}$ & $\mathrm{E}$ & $\mathrm{F}$ & $\mathrm{G}$ & $\mathrm{H}$ & $\mathrm{I}$ \\
\cline { 2 - 12 } & 47.15 & 64.51 & 39.50 & 33.98 & 70.49 & 56.34 & 42.93 & 50.24 & 23.41 \\
\hline
\end{tabular}

\section{B. After the implementation of lesson study}

TABLE 2. Values of cognitive, psychomotor, and attitudes of the students in class XI academic year of 2014/2015 of odd semester

\begin{tabular}{|l|c|c|c|c|c|c|c|c|c|}
\hline $\begin{array}{l}\text { Cognitive } \\
\text { Value }\end{array}$ & $\mathrm{Ma}$ & $\mathrm{Ph}$ & $\mathrm{Ch}$ & $\mathrm{Bi}$ & & & & & \\
\cline { 2 - 12 } & 85 & 78.5 & 81.5 & 85.86 & & & & & \\
\hline $\begin{array}{l}\text { Psychomot } \\
\text { or Value }\end{array}$ & $\mathrm{P}$ & $\mathrm{Q}$ & $\mathrm{R}$ & $\mathrm{S}$ & $\mathrm{T}$ & $\mathrm{U}$ & & & \\
\hline & 64.5 & 66.25 & 65.5 & 65.25 & 54.25 & 41.5 & & & \\
\hline $\begin{array}{l}\text { Attitude } \\
\text { Value }\end{array}$ & $\mathrm{A}$ & $\mathrm{B}$ & $\mathrm{C}$ & $\mathrm{D}$ & $\mathrm{E}$ & $\mathrm{F}$ & $\mathrm{G}$ & $\mathrm{H}$ & $\mathrm{I}$ \\
\cline { 2 - 11 } & 58.75 & 67.50 & 45.37 & 39.50 & 72.43 & 58.5 & 44.71 & 52.5 & 40.50 \\
\hline
\end{tabular}

TABLE 3. Value of cognitive, psychomotor, and attitudes of the students in class XI academic year of 2015/2016 of even semester

\begin{tabular}{|l|c|l|l|l|l|l|l|l|l|}
\hline Cognitive & $\mathrm{Ma}$ & $\mathrm{Ph}$ & $\mathrm{Ch}$ & $\mathrm{Bi}$ & & & & & \\
\cline { 2 - 12 } Value & 87.5 & 80.37 & 82.94 & 86.8 & & & & & \\
\hline $\begin{array}{l}\text { Psychomot } \\
\text { or Value }\end{array}$ & $\mathrm{P}$ & $\mathrm{Q}$ & $\mathrm{R}$ & $\mathrm{S}$ & $\mathrm{T}$ & $\mathrm{U}$ & & & \\
\hline & 73.5 & 74.0 & 74.5 & 72.5 & 63.5 & 64.75 & & & \\
\hline $\begin{array}{l}\text { Attitude } \\
\text { Value }\end{array}$ & $\mathrm{A}$ & $\mathrm{B}$ & $\mathrm{C}$ & $\mathrm{D}$ & $\mathrm{E}$ & $\mathrm{F}$ & $\mathrm{G}$ & $\mathrm{H}$ & $\mathrm{I}$ \\
\cline { 2 - 11 } & 70.00 & 70.49 & 70.49 & 56.34 & 77.00 & 63.00 & 52.75 & 65.00 & 54.25 \\
\hline
\end{tabular}

Note:

Cognitive Value

$\mathrm{Ma}=$ Mathematics $\quad \mathrm{Ch}=$ Chemistry

$\mathrm{Ph}=$ Physics $\quad \mathrm{Bi}=$ Biology

Psychomotor Value

$\mathrm{P} \quad=$ Observation $\quad \mathrm{S}$ = Classification

$\mathrm{Q}=$ Communication $\mathrm{T}=$ Conclusion

$\mathrm{R}=$ Measurement $\mathrm{U}=$ Prediction 
Attitude Value

$\begin{array}{ll}\text { A } & =\text { Religious } \\ \mathrm{B} & =\text { Creativity } \\ \mathrm{C} & =\text { Innovation } \\ \mathrm{D} & =\text { Activity } \\ \mathrm{E} & =\text { Discipline }\end{array}$

$\mathrm{F}=$ Cooperation

$\mathrm{G} \quad=$ Independence

$\mathrm{H}=$ Achievement

I = Responsibility
The results obtained in the Table 1 , Table 2, Table 3 inform that a change in attitudes and skills of students in mathematics, physics, chemistry, and biology after the lesson study, as well as cognitive value. Change in attitude can be seen in Fig. 1, changes to skills in Fig. 2, and cognitive changes in Fig. 3.

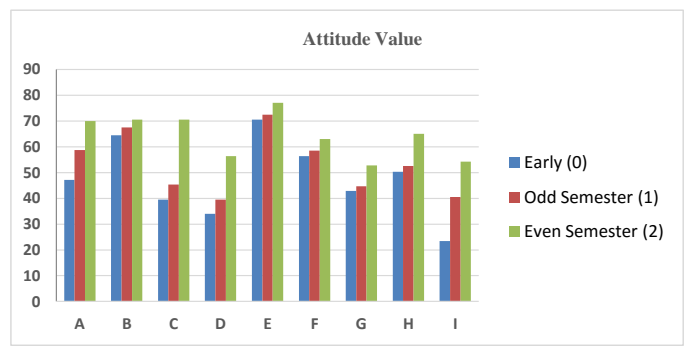

Fig. 1 The Improvement of Students' Attitude

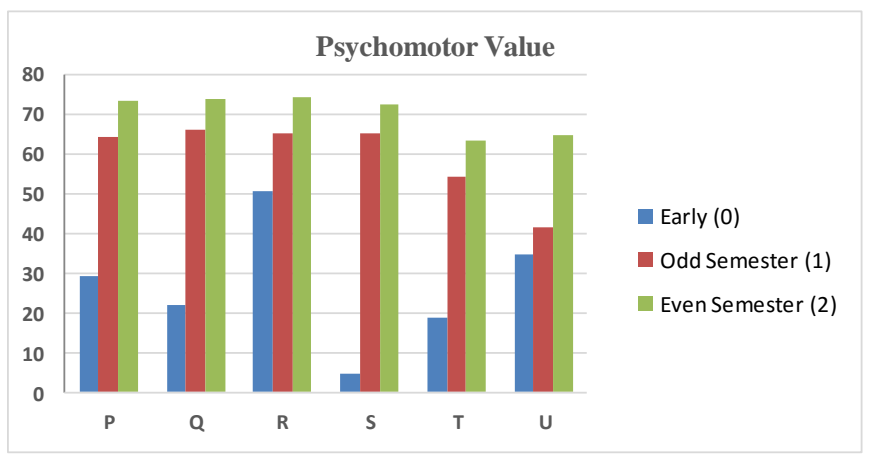

Fig. 2 The Improvement of Psychomotor

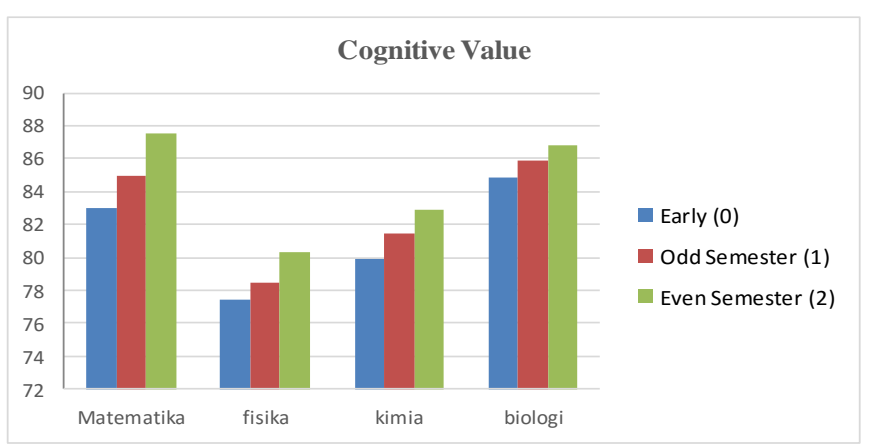

Fig. 3 The Improvement Cognitive

The improvement of cognitive values, skills, and attitudes was possible because the implementation of lesson study emphasized the cooperation of students, creativity, activity, independence, and responsibility of the student. Emphasis on collaborative learning among students is not cooperative. The dialogue occurred between students in heterogeneous groups. Therefore, it is capable of shaping the character and abilities of students. Based on that, the learning lesson study can make students more intelligent, competitive, and comprehensive. The implementation of lesson study in the learning means instilling three domains, namely: cognitive domain, psychomotor domain, and attitude domain.

The implementation of learning using lesson study includes three domains, namely cognitive (knowledge), psychomotor (skills) and attitude (attitude). The application of these three areas in the implementation of learning requires a collaborative learning design and implementation are reflected wisely, ongoing and continuous. In addition, the implementation of a model of learning by teachers is the responsibility of peers as an observer. Things that become obstacles in the learning process are reflected back by the teacher and observer models after the implementation of learning is polite and thoughtful. The outcomes of these reflections become one of the guidelines for the redesign for designing future learning [9].

The implementation of quality learning cannot be separated from a good instructional design. To improve the professionalism of teachers in designing instructional and improve the quality of learning provided a valuable example that directly touches the mind. The phase of the plan, do, and see that understood was begun in demand by teachers in partner schools (4 Secondary Schools in Parigi Moutong district), a positive impact on changing attitudes and skills to students. Lesson study focused on the teaching and learning process that can improve the teachers' professionalism and to improve the learning quality of students [10]. During the implementation of lesson study students' character would be formed due to the lesson study contained a positive activity and brings up the habit and finally would form a positive character.

A positive character will cause the nation to become healthy and the state becomes strong. When seen the success of the Japanese economy that had been destroyed by atomic bombs in Hiroshima and Nagasaki, but the prime minister was collect teachers and instruct teachers to further improve the quality of learning through lesson study. It turns out that through the lesson study the Japanese state is able to return its country to become a country that has world economic power.

\section{CONCLUSION}

After implementing the lesson by applying lesson study in nine characters of students which identified in the learning process namely; religious, creative, innovative, active, disciplined, cooperative, self-reliant, rewarding achievement, responsibility, which have increased, as well as skills, and student knowledge. 


\section{ACKNOWLEDGMENT}

The authors acknowledge to the late Dr. H. Baso Amri Mursyid, M.Si as the chairman of the research, Directorate General of Higher Education, also Ministry of Research, technology, and Higher Education that funded the research, and Head of Educational Board of Parigi Moutong Regency who facilitated the research.

\section{REFERENCES}

[1] H. Wenglinsky, "The link between teacher classroom practices and student academic performance," Education policy analysis archives, vol. 10, p. 12, 2002.

[2] H. Susilo, C. Husnul, J. Ridwan, and Y. Jumiati, "Lesson Study Berbasis Sekolah: Guru Konservatif Menuju Guru Inovatif," Malang: Bayumedia, 2009.

[3] G. Grimsæth and B. O. Hallås, "Lesson study model: The challenge of transforming a global idea into local practice," Policy Futures in Education, vol. 14, pp. 109-122, 2015.

[4] P. R. Indonesia, "Undang-undang Republik Indonesia nomor 20 tahun 2003 tentang sistem pendidikan nasional," 2003.
[5] K. Illeris, "Towards a contemporary and comprehensive theory of learning," International journal of lifelong education, vol. 22, pp. 396406, 2003.

[6] K. Illeris, "Transformative learning in the perspective of a comprehensive learning theory," Journal of Transformative education, vol. 2, pp. 79-89, 2004

[7] F. Lievens, P. Coetsier, F. De Fruyt, and J. De Maeseneer, "Medical students' personality characteristics and academic performance: a five-factor model perspective," Medical education, vol. 36, pp. 10501056, 2002.

[8] E. K. Danasasmita, "Peran Lembaga Pendidikan Guru Dalam Menyiapkan Guru Yang Berkarakter," Tersedia: http://file. upi. edu/Direktori/PROCEEDING/UPIUPSI/2010/Book_1/PERAN_LEMBA GA_PENDIDIKAN_GURU_DALAM_ MENYIAPKAN_GURU_YANG_BERKARAKTER. pdf [29 Juli 2011], 2010.

[9] M. Schmidt, "Preservice string teachers' lesson-planning processes: An exploratory study," Journal of Research in Music Education, vol. 53, pp. 6-25, 2005

[10] C. C. Lewis, R. R. Perry, S. Friedkin, and J. R. Roth, "Improving teaching does improve teachers: Evidence from lesson study," Journal of teacher education, vol. 63, pp. 368-375, 2012. 